\title{
US and India: \\ Paving the road to ensuring peace and prosperity in the Indo-Pacific region
}

\author{
Udita Banerjee*
}

\begin{abstract}
The Indo-Pacific regional construct has been at the helm of international strategic discourse in the recent decade. This region comprises of the whole of Asia-the hub of $21^{\text {st }}$ century commerce, eastern Africa and the key International Shipping Lanes and maritime chokepoints connecting the Indian and the Pacific Oceans. One cannot overstate the salience of this vast regional expanse for the maintenance of well-ordered maritime commerce and security.
\end{abstract}

The formidable rise of China in international affairs causes tension and unease to the United States and India and brings them together to work in tandem at containing China's expansionist rise which has the potential to jeopardize the transparency and inclusiveness underlying the IndoPacific Global Commons. The Covid-19 pandemic has put the world's trust and confidence in China at an all-time low which provides the twin democratic nations with fresh opportunities to resolve outstanding irritants in their bilateral relationship and take a panoramic view of the road to cooperation in the Indo-Pacific region.

This paper attempts to analyze the respective US and Indian Indo-Pacific regional approach to probe prospects for cooperation in securing the multilateral order in the region.

\section{Keywords}

Indo-Pacific region, maritime security, The Belt and Road Initiative, Infrastructure Connectivity, Covid-19, South China Sea, Counter-strategy, Debt trap, Predatory economics.

* Ms. Udita Banerjee is a Research Candidate at UGC Centre for Maritime Studies, Pondicherry University, Puducherry, India. 


\section{US and India: \\ Paving the road to ensuring Peace and Prosperity in the Indo-Pacific region}

\section{Introduction}

The term 'Indo-Pacific' was coined by the strategic and naval expert Dr. Gurpreet S Khurana (2007) while discussing the seminal importance of India-Japan cooperation in ensuring greater economic integration in the Asian hemisphere. He uses the term Indo-Pacific to cover the "maritime spacecomprising the Indian Ocean and the Western Pacific. Littoral to it are the states of Asia (including Western Asia/ Middle East) and eastern Africa" (p.150). The importance of the Sea Lines of Communication (SLOCs) crisscrossing the two oceans makes this bio-geographic space interconnected. These sea lanes serve as crucial maritime routes for global transit in cargo and energy reserves. The seeds of concretization of the concept were sown in the backdrop of the 2004 Indian Ocean tsunami. The countries of the United States, Japan, India and Australia came together to organize extensive Humanitarian Assistance and Disaster Relief (HADR) operations for the disaster-ravaged countries. The four nations recognized the salience of considering the Indian and the Pacific Oceans as one regional space for the maintenance of well-ordered maritime trade and security.

The emergence of the Indo-Pacific discourse, however, did not occur in a geopolitical vacuum. The necessity of preserving the security of these vitalsea lanesarose in the face of an increasingly belligerent Chinaaspiring for unilateral rise as a global power.The hefty might of China as an economic powerhouse, along with a highlymodernised militarynext only to that of the US, enabled China to accumulate influencein the Indo-Pacificregion with a range of non-transparent economic and securitymeasures. The US, in congruence with nations sharing similar geopolitical concerns, aims at securing a liberal-order system in the Indo-Pacific to retain peace, stability andfreedom of navigationin these waters. The rising international profile of India as a responsible security player along with its undulating strategic rivalry with China proves conducive for US-India partnership efforts to contain China's hegemonic aspirations as evidenced through forceful occupation and militarization of islands in the South China Sea. India views with apprehension the capability of China to encircle India in its own maritime neighbourhood by developing military bases in littorals surroundingIndia as evinced through China's assertive show of military force to grab islands in 
the South China Sea and the influx of mammoth economic investments in the Indian Ocean region. Professor Medcalf (2016) opines, “The Himalayas are no longer a barrier to Beijing's strategic ambition. China has crossed them-by sea" (p.64).At this juncture this paper shall analyze how the Belt and Road Initiative (BRI)acts as the 'Chinese' Indo-Pacific strategyto connect resource-rich countries of Europe, Asia and Africa with China and analyze the respective US and Indian IndoPacific regional approach to probe prospects for cooperation in securing the multilateral order in the region.

\section{The BRI: China's Indo-Pacific expansion strategy}

The usage of the term 'Indo-Pacific' gained recognition in policy and strategic circles around the first decade of the current century. In 2007, Japan's former Prime Minister Shinzo Abe spoke of the 'Confluence of the two seas' in his address to the Indian Parliament denoting the interconnectedness of the Indian and the Pacific Oceans. In 2013, the former Indonesian Foreign Minister Marty Natalegwa had even proposed an Indo-Pacific Treaty of Friendship and Cooperation to be signed by all the states concerned, much in line with the rules of engagement which take place through ASEAN and its affiliated entities (Ram, 2015).Given the gaping diversity of this vast region the proposed treaty could not bear fruit. TheIndo-Pacific ocean space encompasses several strategic sea lanes carrying almost two-thirds of the world's energy; half of global containerized cargo, and a third of the world's bulk cargo (Singh, 2018). The clear linkage of economic activity that spans across trade and energy routes from the Suez and the Strait of Hormuz on the one end, to the Malacca, Sunda, and Lombok straits leading into the South China Sea on the other, highlights the necessity of treating the region as a continuum (Ibid.).Further, the region is home to nearly three billion people and a combined GDP of almost \$20 trillion (Wadhwa, 2018).The Indo-Pacific region is debated to be ranging from the eastern shores of Africa to the west coast of the United States, albeit with variations depending on each actor's geographic positioning in the expanse (Das, 2019).

Post the 2008 global financial crisis, most Western countries turned to protectionist economic measures in the form of restricting imports and providing bail-out measures to national companies which dealt a sharp blow to the Chinese export-led economic growth model. The US, for example, instituted the Recovery and Reinvestment Act of 2009 which included a "buy American" clause 
to encourage purchase of domestic products and European countries such as France, Germany and UK announced bail-out measures for their automotive industries (UNCTAD, 2010). Further, with several decades of economic reforms that led to exponential growth in exports and influx of foreign direct investment, China was now experiencing 'twin surpluses'of capital and current accounts manifested in liquidity, overinvestment, soaring asset prices and external trade friction (Ohashi, 2018a).The announcement of the US' 'Pivot to Asia' or the Rebalance strategy indicated a shift in US focus from its global commitments in general, and the Middle East in particular, to a rising Asia-the prophesied centre of $21^{\text {st }}$ century commerce, through economic involvement and increased security presence. All these reasons pushed China to look for acountermeasurethrough economic investment by opening up relatively underexplored markets of Central and Eastern Europe and African nations to draw the Indo-Pacific countries into its orbit.

Since the inception of the term Indo-Pacific, China has revealed considerable unease at the nomenclature which in its view is directed towards its containment. However, considering the phenomenal importance of the region for $21^{\text {st }}$ century commerce and amidst the cacophony of divergent Indo-Pacific visions put forth by several nations, China eyes the opportunity to act on expanding its hold over the region without the necessity to declare support for the nomenclature. The BRI is China's geo-economic strategy to amass influence in the Indo-Pacific region through economic investments. The BRI is characterized by five cooperation priorities: policy coordination with participant nations, connectivity facilitation, unimpeded trade, financial integration and people-to-people contact (Belt and Road Initiative official website). Proposed in 2013 by Chinese President Xi Jinping in the form of an economic belt and a maritime road at Kazakhstan and Indonesia respectively, the BRI is a two-way integration plan to connect the three continents through overland routes-the Silk Road Economic Belt and a maritime road- the $21^{\text {st }}$ Century Maritime Silk Road. Towards that end, China set up financial institutions of the Asian Infrastructure Investment Bank (AIIB) and the Silk Road Fund (SRF) to support regional infrastructure connectivity projects in the Indo-Pacific region. The initial years of the BRI witnessed massive support with several countries signing up for italong withmany developed Western countries such as the UK, France and Germany joining the China-backed AIIB as founding membersand also expressing enthusiasm to support BRI's infrastructure projects. The 
current scenario however witnesses several countries engulfed in distrust about the prospects for mutual development under the aegis of BRI-funded infrastructure connectivity projects.

A brief sector-wise analysis of BRI investment will be relevant here. The first is infrastructurerelated industries (construction, equipment manufacture, and building materials). Most of the BRI countries are developing and transitional economies with a huge potential demand for infrastructure development, which provide a lot of opportunities for not only China's competitive industries but also its sunset industries with overcapacity in steel and iron, textiles, chemicals, to name a few. The second is natural resources and energy. The BRI countries are well endowed with natural resources. China's important strategic goal is to secure stable supplies of energy and to diversify their sources and transport routes. The third is overseas contracted projects undertaken by China's contractors and civil engineering firms. They have outstanding international competitiveness and are very aggressively developing new markets all over the world (Ohashi, 2018b). However despiteclaims of two-way development, there are suspicions that BRIis preponderantly tilted in favour of Chinese economic growth. Firstly, with implementation of BRI projects, China's exports haveexceeded imports by leaps and bounds. The BRI participant countries are mostly low-development countries with inadequate funds at their disposal to meet the infrastructure connectivity demands and depend on credits and development aid granted by China for project completion. In the future if the projects do not yield sufficient revenues the countries are forced to mortgage their strategic assets to China to pay off the debts. The Piraeus port in Greece, the Hambantota Port in Sri Lanka and the Gwadar Port in Pakistan are some examples of such Chinese takeovers due to unsustainable debt accumulation by participant nations. Of these in the first two ports China has acquired majority stakes and taken over their management on 35-year and 99-year lease respectively while in the third China has financed considerably for the development of the port and taken over its control operations. Further, financial assistance for BRI projectsis extended to countries without attachment of policy condition such as strengthening governance through improvements in financial transparency, fulfilling accountability to citizens and conducting anti-corruption activities. Suchfactors can act as infirmities in the future with several corruption-ridden and low efficiency governments indeveloping countries failing to utilize the funds for stated purposes and ending up adversely affecting national and regional development. BRI infrastructure connectivity has improved economic prosperity in some countries but 
infrastructure development must also be supported by simultaneous national policy reforms. A World Bank Group study highlights that BRI countries' contribution to global exports has nearly doubled in the last two decades. But a handful of BRI economies, most notably China, are responsible for the lion's share of such exports. Further, there are potential environmental, social, and corruption risks associated with any large infrastructure project. These could include, for example, biodiversity loss, environmental degradation, or elite capture. These risks are especially significant in countries involved in the BRI, which tend to have relatively weak governance (Ruta, 2018). Thus, development assistance should come with strict condition in order to prevent lopsided development. China has shown scant regard for such suggestions.

There are also apprehensions that BRI increases China's regional familiarisation in the Indian Ocean and the acquired strategic assets can in the future act as military bases to launch attacks against India. China has engulfed India’s neighbouring countries such as Sri Lanka, the Maldives and its 'all-weather ally' Pakistan into severe debt crisis, from which it is difficult to disentangle. This ensures China's sustained presence in India's neighbourhood on the pretext of securing its BRI investments and in the process master sea control tactics. China's technological assistance to development-starved Pakistan to help develop its sea-based tactical nuclear weapons to offset India's conventional military superiority against Pakistan exemplifies this (Khurana, 2019).The BRI, in sum, exposes China's neo-colonial extractive mindset to exploit partner nations for resources and obtain strategic advantages to encircle India in its own maritime neighbourhood and in the long-run surpass the US as the key player in the Indo-Pacific, in congruence with its 'Middle Kingdom' mindset of cultural superiority.The US-India cooperation at all levels-economic, security, strategic and diplomatic is urgently called for to counter the Chinese Indo-Pacific strategy and vision. The next section shall focus on the respective US and Indian Indo-Pacific strategies in the ongoing decadeand the opportunities forcooperation to fructify the Indo-Pacific initiative for ensuring the freedom and openness associated with the oceans.

\section{US presence in the Indo-Pacific region: Can the Pivot remain focused?}

The US has been serving as the dominant security and strategic power in both the Indian and the Pacific Oceans since the end of the World War II, declining to retreat into its erstwhile shell of 
isolationism. The US' vast resources have helped to create and sustain a multilateral order resting on international norms and rules which have served as the basis of what Fareed Zakaria called the "rise of the rest" (Stuart, 2016).However, a more enhanced and focused engagementwith the AsiaPacific region was adopted by President Barack Obama in his declared 'Pivot to Asia'policy during his presidential term. This geographic shift to the Asia-Pacific region had more to it than economic pulls of the Asian hemisphere. The shift was towered by a geo-strategic necessity to address the neo-containment of an expansionist and revisionist China from unsettling US superpower status.

China's pumping billions (or trillions) of dollars in aid and investment projects into several Asian and African economies and building institutional alternatives such as the AIIB, SRF and the New Development Bank (NDB) to the US-sponsored economic order have exacerbated US apprehensions regarding China's ambitions. China's layered Indo-Pacific strategy consists of 'gray zone' tactics in its 'near seas' and 'influence accumulation' in 'far seas' (Cooper and Shearer, 2017). In its maritime neighbourhood of the South China Sea, China has displayed sufficient muscle-flexing with respect to counterclaimant countries over island features, reefs and baysdue to its asymmetric economic and military might.In the East China Sea, it has engaged in continued contestation of the Senkaku/Diayou Islands with Japan, including the establishment of an Air Defence Identification Zone (ADIZ) over the region. In the 'far seas' of the Indian Ocean, China has laboured steadily to gather influence by economic inducements and infrastructural capacitybuilding already described before.

The Indo-Pacific region, as defined by the Trump administration, stretching from the western Indian Ocean that serves as the mouth to the key energy routes emanating from the Persian Gulf and the Strait of Hormuz to the western sphere of the Pacific Ocean, comprising key US island chains of strategic interest, accommodates this power transition challenge for the US. The Trump Administration alleges that previous US administrations- Clinton, Bush and even Obama administration- misread Beijing's strategic intentions; while they sought to engage China constructively in shaping world affairs, China worked, both overtly and covertly, to replace US as the primary power in Asia and the world. Committing massive theft of US Intellectual Property Rights, forceful militarization of artificial islands in the South China Sea, manipulation of currencyfor trade benefits and threatening of Taiwan bear substantive evidence for Trump's 
assertions (CFR, 2019). Based on this premise, the US “counter-strategy" is building up of its own military strength ("internal balancing”) and seeking allies and partners ("external balancing”) across the Indo-Pacific (Scott, 2018). The US declares its vision of the Indo-Pacific to be in close alignment with Japan's Free and Open Indo-Pacific concept, India's Act East Policy, Australia's Indo-Pacific concept, Republic of Korea's New Southern Policy and Taiwan's New Southbound Policy (DoS, USA. 2019a). Thus, US Indo-Pacific policy is unequivocally addressed to democratic nations in the Asia-Pacific region to work in close alignmentwith the US to combat China's expansionist and hegemonic aspirations.

In 2018, the US renamed its Pacific Command as the Indo-Pacific Command (USINDOPACOM) recognising the salience of treating the Indian and the Pacific Ocean as an intertwined region requiring increased US security presence. The name change is noteworthy in today's geostrategic environment-with its first overseas base in Africa, Chinese naval vessels transiting the Indian Ocean routinely, and a budding list of maritime infrastructure projects, China's interests are no longer bounded by the Pacific; they now span the Indian Ocean too (Vorndick, 2018). A speech by Admiral Phil Davidson, Command Head of the USINDOPACOM, at the Lowy Institute in Australia mentioned a "strategic competition" between a "Beijing-centric order" and "Free and Open Indo-Pacific". He reiterated US' committed resolve to Japan and the Philippines to come to their rescue in the event of an armed attack (as part of their mutual defense treaty obligations), renewed US-Singapore Memorandum of Understanding (MoU) extending US access to defenserelated facilities and logistics provided by Singapore and deepening economic relationships with the Freely Associated States of Palau, Micronesia and the Marshall Islands (Davidson P, 2020).This can be inferred as US strengthening its basing network for forward deployment of military power to encumber Chinese armed attack, real andperceived, and other threats to US interests in the region. According to senior Pentagon correspondent Aaron Mehta (2020) the US administration has recently submitted a \$20-billion wish list to the US Congress for advanced weaponry stock piles and millions in aid for partner nations in upping their defence capacities to deter Chinese military in the region. The funding demanded by Davidson can be broken into five categories of concrete strategies-Joint Force Lethality; Force design and posture; strengthen allies and partners; exercises, experimentation and innovation and logistics and security enablers. The US has also strengthened cooperation at the bilateral and trilateral levels to ensure protection of 
maritime security throughjoint military exercises like the Talisman Saber (US And Australia) and the Malabar trilateralnaval exercise (Japan-India-US); annual meetings such as the AUSMIN between US Secretaries of State and Defence with their Australian counterparts; and signing logistics sharing agreement such as the Logistics Exchange Memorandum of Agreement (LEMOA)and Communications Compatibility and Security Agreement(COMCASA)with India (in 2016 and 2018 respectively) to ensure security development in conjunction with partner nations.

Under the Trump administration, in 2018, the US launched the US-Support for Economic Growth in Asia (US-SEGA), a technical assistance program, to help partners adopt high-standard comprehensive trade and investment policies in areas like regulatory requirements, women in science and technology, digital economy and cyber security. The same year the US launched Asia EDGE (Enhancing Development and Growth through Energy)initiative which is a whole-ofgovernment effort to support energy security, catalyze private sector investment in energy markets and help leverage development finance and export credit towards catalysing such investments in the Indo-Pacific region (DoS, USA, 2019b). The US, under President Trump, has also come up with a signature initiative called the Better Utilization of Investments Leading to Development Act (BUILD Act) which aims to facilitate the participation of the US private sector in promoting economic development of low or lower-middle-income countries. The Act ensures that government or quasi-government-backedinstitutions lend development finance asassistance for building skills and capacity in low-development countries in fields of financial institutions, clean energy, sanitation facilities andinfrastructural facilities like transport and telecommunications.At the 2018 Asia Pacific Economic Cooperation (APEC) Summit US Vice President Mike Pencetook a dig at China's predatory economic practices to aver that Washington's approach to infrastructure development is a "better option" as it does not offer "a constricting belt or a one-way road" (Agence, 2018).

While the US investments and infrastructural development initiatives under the Trump administration have earned high receptivity among Asian economies, bilateral and multilateral trade relationships with the US have been negatively received (Pitakdumrongit, 2019). Trump has subjected not only China, but several US allies and friends to every sort of complaint regarding 
what he perceives as 'unfair' trade practices. The US decision to pull out of the Trans Pacific Partnership (TPP) unilaterally in 2017, clearly seemed to be lacking in foresight. If signed, the deal would have enabled lower export tariffs on US goods entering the Asian markets and propelled significant economic growth both for the US as well as constituent partners.It would have cemented US position in the Asian economic region as a credible alternative to China as economic necessities often trump security considerations. This has been evident in the South China Sea case where despite being bullied by China on several accounts, the counter-claimant countries have refused to lock horns with China including countries like Taiwan and Vietnam which have experienced historically fragile relations with the Middle Kingdom. Instead, they prefer to engage in negotiations-mostly bilateral, sometimes multilateral, to resolve outstanding disputes as all Southeast Asian countries are deeplyeconomically engaged with China. As diplomats Mahbubani and Sng (2017) observe that the US has eternally failed to maintain a consistent relationship of friendship and involvement with the Association of South-East Asian Nations (ASEAN), the emblem organisation of Southeast Asia, despite ASEAN being born "pro-American" (p.82). Communist China, on the other hand, had acted deftly by being the first country to propose setting up a Free Trade Agreement with ASEAN in 2000 besides offering unilateral concessions and an "early harvest" as part of the agreement (p.99-100).

To sum up, the Trump administration has not minced words in adopting a confrontational approach with regard to China. The US has called uponpartner nations to undertake a fair share of the burden to maintain the freedom and openness of the geopolitical space. Challenges notwithstanding, there is a demonstrated reluctance to embrace China-supported multilateral institutions outside the developing world especially when China itself has shown reluctance to involve multilateral institutions in resolving disputes in the South China Sea (Keithley, 2014). Further, the unsustainable debts accumulated under Chinese-sponsored BRI projects have given many countries much food for thought to reconsider participation in Chinese-led economic initiatives on an extensive scale.The US has a clear edge over China with regard to having the image of a responsible power. Every year countless people from all over the world enter America with high aspirations for receiving the best education and jobs. American companies doing business all over the world has shown considerable commitment to uphold financially transparent mechanisms of doing business and training local talent pools thus promoting mutual development. However, 
under the Trump administration, the US has displayed certain protectionist tendencies by building invisible border walls between the US and the rest of the world through restrictive visa issuing procedures and trade practices. This does not bode well for the image of America as a responsible superpower. The US should manifest a deep-consensus approach to ensure the Indo-Pacific community of its commitment to fulfil its responsibilities which are not subject tothe whims and fancies of changing leadership.

\section{India and the Indo-Pacific region: The Elephant on the rise}

India, since times immemorial, has engaged in trade and cultural relations with countries around the world. India's unique maritime geography with a central location and reach across the Indian Ocean Region (IOR) bolstered her development as a leading emporium of Asia. The horizons of her trade extended from the eastern and southern coasts of Africa to Southeast Asia, which closely resembles the Indo-Pacific region of today.The deep-rooted tiesof trade, culture and religion between India and Southeast Asia resulted in the establishment of several kingdoms in the latter region such as Bali, Funan, Angkor and the Srivijaya with strong Indian cultural influences. Given the peninsular character of India and her essential dependence on maritime routes for trade and traffic, the Indian Ocean has had a preponderant influence upon the Indianpolity since antiquity.

Due to force of circumstances, India was forced to look inward to strengthen its military capacity since the 1960s following Chinese aggression, as I.K Gujral said in a speech in Singapore "Colonialism and the Cold War...., drew artificial boundaries between us" (Gujral, 1996).In the post-Cold War world, India reactivated her involvement with Southeast Asian countries with the inauguration of the 'Look East' and subsequently 'Act East' foreign policies. The Act East Policy enabled India to enlarge its vision of action from the IOR toinclude the Western realm of the Pacific Ocean as the area of India's economicand strategic interests. India's Indo-Pacific strategy found clear expression for the first time in the references made by incumbent Prime Minister Narendra Modi's speech at the Shangri-La Dialogue in Singapore in 2018. In the speech he called for a free, open and inclusive Indo-Pacific region, resting on territorial integrity and sovereignty of all nations and amicable settlement of disputes based on dialogue and adherence to international law. While highlighting the importance of the Indian Ocean to our national security and economic 
prosperity, he asserted that to the east the Straits of Malacca and the South China Sea connect India to the Pacific region to most of our 'major' partners of ASEAN, Japan, Republic of Korea, China and the Americas (MEA, Government of India, 2018). Shortly thereafter, a separate Indo-Pacific division in the Ministry of External Affairs was established to provide more teeth to the IndoPacific strategy. Further, initiatives such as the Indo-Pacific Oceans' Initiative (IPOI) have been launched by Prime Minister Modi at the East Asia Summit in 2019 to focus cooperation on issues of maritime security, maritime ecology, disaster reduction and management, trade connectivity and maritime transport (Indo-Pacific Division Briefs, MEA, 2020). The India-Myanmar-Thailand Trilateral Highway and the Kaladan Multi-Modal Transit Transport projects are under progress to promote multi-modal connectivity between India and the Southeast Asian countries. IndiaASEAN FTA promotes trade in goods, services and investment both ways amounting about a hundred billion dollars and there are plans to increase the value to $\$ 200$ billion by 2022 (IndoPacific Division Briefs, MEA, 2020). More projects to boost connectivity and infrastructure development initiatives with ASEAN nations are in the offing.

The South Asian and the Bay of Bengal region remains India's top priority under the Modi government. Consequently, with the moribund nature of the South Asian Association for Regional Cooperation (SAARC) owing to persistent India-Pakistan differences in failing to reach a consensus on issues requiring decisions, India has resorted to the Bay of Bengal Initiative for Multi-Sectoral Technical and Economic Cooperation (BIMSTEC) to promote regional integration. The BIMSTEC was resurrected with the BRICS-BIMSTEC Outreach Summit in 2016 to promote multi-modal physical connectivity in the Bay of Bengal region. India has assisted the Maldives with significant budgetary support to reduce its debt burden to China as well as identified three projects for cooperation: water supply and sewage treatment in 36 islands, a development centre at Addu city and a small and medium enterprises development financing project (Dixit, 2019). India has also extended credits and investments in a number of projects in Sri Lanka in areas of housing facilities, medical services, solar projects and combating terrorism. Sri Lanka'sincumbent government terms its 'India first approach' in foreign policyaffairs a strategic priority. India has also settled its maritime border dispute with Bangladesh in accordance with the verdictdelivered by the United Nations' Permanent Court of Arbitration in 2014to bring to closure a long-pending issue in the larger interest of India-Bangladesh relations. India has also launched project Mausam 
in 2014 to renew cultural links among IOR countries and the initiative called SAGAR- Security and Growth for All in the Region-launched in 2015, calls for inclusive all-round development of the region as a whole.

India's policy with regard to the Western Indian Ocean region too deserves mention here. The Western Indian Ocean (WIO) region comprises of ten countries: Somalia, Kenya, Tanzania, Mozambique, South Africa, Comoros, Madagascar, Seychelles, Mauritius and the French overseas territory of Reunion (Western Indian Ocean Marine Science Association official website). The WIO region is a key part of India's Indo-Pacific vision hence strengthened cooperation with India is on the rise to secure good order at sea.The official Indian Maritime Security Strategy document (2015) avers that several 'choke points' in the WIO-Cape of Good Hope, Mozambique Channel, Bab-el-Mandeb, Suez Canal and the Strait of Hormuz- are areas of 'primary interest' for India's trade, especially energy trade as India imports significant energy resources from Africa as well as because these choke points serve as key International Shipping Lanes (ISLs). Often, the economically challenged African countries, riddled in corruption and inefficiency, are unable to address pressing issues of maritime safety and marine resources protection. India has therefore signed bilateral MoUs with the ten African nations in addressing issues of maritime piracy and terrorism and humanitarian crises which pose severe threats to ISLs straddling the region. Further, training of naval, defence and civilian personnel of African countries have been implemented on a regular basisespecially under India's International Technical and Economic Programme (ITEC).Displaying more purposeful maritime diplomacy, Indian naval ships increased their port visits to Africa's East coast and Indian Ocean island states where incidences of piracy run high(Singh, 2015). The Indian Navy was one of the firstnavies to commence anti-piracy patrols in the Gulf of Aden and have sincebeen on continuous deployment. More recent efforts include India signing a logistics agreement with France that would allow it access to French military bases in Djibouti and the Reunion Islands. India has also expressed interest in building a naval facility in Seychelles' Assumption Island which has been deemed dead due to fears of militarization and environmental damage. India has enhanced its own capabilities to extend operational influence in the IOR which includes upgrading its Coastal Surveillance Network that would provide live monitoring of ship movements in the IOR and connect Indian radars to similar systems in Sri Lanka, Maldives, Mauritius and Seychelles(Todi, 2019).According 
to the Swarajya (2019) the setting up of the Information Fusion Centre for the Indian Ocean Region (IOR-IFC) by the Indian Navy is a commendable step to engage in collective efforts in the IOR for collation, fusion and dissemination of information involving high tech, state-of-the-art techniques for addressing challenges to maritime security such as piracy, terrorism, human and contraband trafficking and unregulated fishing. The IFC-IOR has established linkages with 13 international maritime agencies and more than 16 countries. The centre has been established to address the twin requirements of situational awareness and law enforcement.

An assessment of India's Indo-Pacific strategy reveals India is beginning to embrace a wider regional approach with respect to the Indo-Pacific region at a time when regional inter-state rivalries and non-traditional maritime security challenges run rife.China's economic investments in the African countries already surpasses that of India and Indian security experts fear that in the future China's port investments in the IOR will be used to encircle India strategically, as if by a string of pearls (SWP, 2019). India needs to hasten its efforts or it stands the risk of losing benefits accruing from its geographical advantages in the region.For example, to ensure peace and stability in the IOR beyond the protection of its own shipping routes and Exclusive Economic Zones (EEZs), India should considercooperating closely with regional mechanisms including the Djibouti Code of Conduct network, Regional Maritime Information Fusion Center (RMIFC) in Madagascar and Regional Coordination Operations Center (RCOC) in Seychelles to develop shared standard operating procedures (Mishra, 2019).The Indian Maritime Security Strategy document, although describes eloquently India's maritime security strategy for effective maritime domain governance, falls woefully short in terming potential aggressor states in the region. Greater liberalisation and reform in the Indian defence industry is sought-in promoting closer security relations with IOR countries especially in WIO region which is predisposed to high incidences of maritime security threats. However, with a greater focus on inter-institutional dialogues among key Indo-Pacific countries in the form of Quadrilateral Security Dialogue or the Quad 2.0, India is surely displaying its emerging potential as a responsible player in the region. As a strategic competitor of China, India is well aware that its foreign policy resources are no match to that of China (SWPa, 2019) and therefore the latter should rely more on its soft power potential to make credible a concrete and effective Indo-Pacific regional policy. India's Project Mausam and the SAGAR initiatives can play an effective role in this regard. 


\section{India and the US in the Indo-Pacific strategic discourse: Differences in Approach and the road ahead}

With India's concern over China's growing presence in South Asia and the Indian Ocean, and the US also seeking to counter China's growing global influence, India and the US have reached an increasing level of strategic convergence on the need to counter China's role in the Indo-Pacific region (Levesques and Solanki, 2020a). The oceans are an important part of the Global Commons and both India and the US uphold their peaceful use a sovereign right of all nations. India's enduring tactical advantage in the Indian Ocean coupled with a maritime neighborhood that is relatively peaceful (compared to its land borders) has worked to India's advantage. Additionally, the US is the power that can still 'shape' Indian Ocean events, given its presence in Bahrain, Diego Garcia and Western Australia (Scott, 2013).

India-US cooperation has been on an upswing in the last few years. US-India two-way trade is today valued at around 142 billion dollars and currently India is US' eighth-largest trading partner in goods and services (Ayres, 2020a).The US acknowledgement of India as a 'Major Defence Partner' isanother historic first: it provides the latter with access to advanced US defence technologies, at par with US' other allies despite not being an ally in legally binding terms. The US President Trump's visit to India in February 2020culminated with India signing the Letter of Acceptance (LOA) with the US for the acquisition of 24 MH-60R Seahawk anti-submarine warfare helicopters. India also signed a LOA with the US for the sale of six additional AH64E Apache Guardian attack helicopters. This is in addition to the contract between India and Boeing for 22 Apache helicopters and 15 Chinook helicopters, finalised in September 2015 (Levesques and Solanki, 2020b).These developments have made the US India's second-largest arms supplier. The Malabar Naval Exercise has been in place since 1992 to maintain goodwill between the two countries and India-US, in 2019, concluded their first tri-service military exercise for conducting HADR operations, codenamed 'Tiger Triumph', in reflection of growing congruence in their bilateral defence ties. Pacts like the LEMOA and COMCASA enable India smooth accesstohighly coded intelligence and communication equipmentsto monitor the Indian Ocean region more thoroughly. COMCASA especially will grant India access to highly encrypted, real-time American intelligence on military deployments by China and Pakistan (The Economic Times 2018) enablingIndian military greater preparedness to face challenges in the maritime 
domain. India has also signed logistics sharing pacts with France, Singapore, Australia, South Korea and most recently, Japan.

Along with new-found bilateral optimism, there is afair amount of irritants in the US-India relationship. For instance, the Trump administration initially defined the Indo-Pacific region as spanning from the west coast of the US to the western shores of India (DoD, 2019), thus neglecting the WIO region which is a key part of India's vision of its Indo-Pacific policy. WIO is an area containing some of the key chokepoints in the Indian Ocean and is replete with non-traditional security threats.Coordinated presence in the region calls for more commitment from the US to the WIO (the US has only recently recognized the importance of the WIO). China, the common adversary, has expanded its presence in the region through hefty economic investments and BRI infrastructure connectivity in African countries. China has also stepped up its security presence in the WIO through movement of massive surface and subsurface fleet in the name of conducting anti-piracy operationsand has established its first overseas military base at Djibouti. After several years of bureaucratic inertia, upgrading US-India defence partnership has proved to be a step in the right direction and the signing of LEMOA and COMCASA agreements makes India far more confident in its strides as a vigilantstakeholder in the region. The US and India should now expedite the signing of their third agreement on sharing of advanced satellite and topographical data for long-range navigation termed as the Basic Exchange and Cooperation Agreement (BECA) for cooperation in the geospatial data-sharing. Further, bilateral joint naval exercises can be conducted in the WIO region, given the historical mutual trust enjoyed between India and the African countries.

Trade tensions between India and the US, which has surfaced in the recent past, may act as a major deterrent to smooth bilateral relations. US removal of India's Generalized System of Preferences (GSP) status in favour of more balanced trade to reduce the trade surplus enjoyed by India led the latter imposing retaliatory tariffs on US exports and the US filing a dispute at the World Trade Organization (WTO) (Ayres, 2020b). The biggest hurdle, however, is the long-standing demand from the US for greater market access for its farm and manufacturing products, dairy items and medical devices on which there are heavy protectionist restrictions in India to protect its own important agrarian and pharmaceutical businesses. Also, Trump has often berated India as a tariff 
king and the India-US trade deal has for a long time been one in the making, yet to be worked out. US has also placed India on its priority watch list over issues of intellectual property as US asserts that India has weak patent protection mechanisms in place and indulges in piracy of software, film and music productions. Notwithstanding disputes, the two countries should be mindful that the trade deficit between the US and India is minuscule in comparison to that between US and China or India and China and to forge a multi-polar Indo-Pacific regionthey need to resolve their differences with greater dexterity keeping in mind the need for cooperation and partnership. Trade negotiators on both sides should up the ante in ironing out the differences and moving forward in chalking out a major bilateral trade deal which would foster closer relations between the two nations.

The novel Coronavirus called the SARS-CoV-2 which induced the COVID-19 infections that were first witnessed in the city of Wuhan in Beijing in 2019 has spread like wildfire all over the globetriggering a pandemic which has got economies of several nations in crisis. To contain the spread of the virus most countries imposed strict lockdowns to ensure physical distancing which consequently affected economic performance adversely. Reeling under the crisis, many countries called for an impartial investigation over the origins of the virus and also expressed disappointment over China's under-reporting ofits infection rates. China has severely admonished countries which have asked for the investigation and tried to silence such allegations with threats of economic sanctions and blatant display of asymmetric military might such as witnessed in the South China Sea and the border tensionescalationswith India. Such behaviours have blasted the myth of China's peaceful rise and global trust deficit in China runs at an all-time-high. The US and India have been victims of the pandemic losing innumerable lives and livelihoods for which the frustration with China (with whom both share a debilitating trade deficit) has widened. Inking the US-India trade deal at this juncture can ensure greater cooperation between them. Also, India should consider diversifying its imports in order to reduce some of its dependence on China- especially in the automotive and electronics industries and switch to the US. That would also aid India in reducing some of the trade surplus with the US that the latter has been vehemently asking for. Further, the US' tackling of the virus, contrary to the image of a global power, has failed miserably on three fronts- domestic governance, provision of global public goods and an ability and willingness to muster and coordinate a global response to crises (Campbell and Doshi, 2020).The need-of-the- 
hour medical equipments - face masks, protective suits, hand sanitizers, testing kits and medicines were in abundant short supply in the early stages of the spread when the requirement for them were the most. However, all is not lost as the US is one of the most developed countries in the world and its edge in the sphere of medical innovation and biotechnology can aid in the early generation of a vaccine that is beingtouted as the panacea to the COVID illness. India-US healthcare partnership is proving beneficial in the battle against COVID-19 as evidenced through plans to work together on vaccine research and testing for COVID-19 (Haider, 2020).US' enormous experience in medical science can act as a booster to India's own research in developing a vaccine which is both safe and cost-effective.Also, India's supply of large doses of hydroxychloroquine to the US in its pressing hour of need was lauded by Trump with promise of reciprocity by donating ventilators. Thus, India-US cooperation in the economic and health sectors can be strengthened to reduce overdependence on China and strengthen the bilateral relationship.

Amidst the COVID-19 pandemic, many countries are turning in to protectionism to save precious jobs for their citizens at home which definitely comes at the cost of eating into the jobs of immigrants and temporary workers hired on a contractual basis. The US has been in the limelight for a while now with regard to temporary suspension of $\mathrm{H}-1 \mathrm{~B}$ visas until next year. For many Indians, H-1B visas are the medium to fulfil their 'America Dream' and the recent presidential order has been quite hard on them. The US should reconsider such blinkered attitude in a world which is excessively globalized as best evinced by the COVID-19 pandemic. Bilateral relationships are cemented on the bedrock of people-to-people relations at the level of civil society. India's bond with the US and other Western countries comes from this relationship at the grassroots level which has been carefully cultivated through scholarships, internships and lucrative employment opportunities dished out over the years. In a day and age when the compulsions of integration and collaboration are at an all-time high, building walls of protectionism shall only foment trouble and mistrust in the bilateral relationship. On the whole, the US-India relationship has progressed significantly in the realm of defence and security cooperation owing to the formidable challenges in the Indo-Pacific region and progress follows in other crucial sectors despite the presence of disagreements that need careful resolution. 


\section{Conclusion}

To sum up, the US-India bilateral relationship has witnessed ebb and flow over the years to reach a position of mutual trust and goodwill. The Indo-Pacific region, with its immanent opportunities and challenges, provides a unique scope for the Indian and the American Administrations to work together to counter Chinese aggression and hegemonic expansionism. Notwithstanding differences, both countries are taking measured but confident steps to take the relationship forward. India has diversified its defence import base to procure more defence equipments from the US and the under the 'Make in India' initiative is attracting manufacturing businesses from abroad while the US has diversified its range of security partnerships to include growing economies like India in its balance of power game with China. The US-propagated values of democracy, rule of law, human rights and transparency have upheld peace and stability in the world in the post-World War II period which is currently under stress from Chinese ambitions. It is thus binding on the two democracies to work together to ensure a free and open Indo-Pacific region beneficial for the prosperity of all the concerned stakeholders.

\section{Acknowledgements}

This paper has been made possible by the general support extended by my guide Prof. A. Subramanyam Raju, Professor, Pondicherry University.

\section{References}

Khurana, G.S. (2007). Security of Sea Lines: Prospects for India-Japan Cooperation. Strategic Analysis, 31(1), Pp 139-153.

Medcalf, R. (2016). The Western Indo-Pacific: India, China and the Terms of Engagement. Asia Policy, 22, 61-68.

Ram, V. (2015).The Proposal for an Indo-Pacific Treaty of Friendship and Cooperation: A Critical Reassessment. Journal of ASEAN Studies, 3(1), 22-31.

Singh, A. (2018). Geopolitics in the Indo-Pacific and Disputes in the South China Sea. The IndoPacific Region. In S. Chandra and B. Ghoshal(Eds.), The Indo-Pacific Axis: Peace and Prosperity or Conflict? (Pp.61). New Delhi, India: Manohar Publishers and Distributors. Ibid.Pp 60. 
Wadhwa, A. (2018). India's Approach to the Indo-Pacific. In B. Ghoshal.\&S. Chandra(Eds.), The Indo-Pacific Axis: Peace and Prosperity or Conflict? (First, Pp.24). New Delhi, India: Manohar Publishers and Distributors.

Das, U. (2019). What Is the Indo-Pacific? Retrieved September 24, 2020 from https://thediplomat.com/2019/07/what-is-the-indo-pacific/

UNCTAD, (2019).International Trade After the Economic crisis: Challenges and New Opportunities. Retrieved October 16, 2020 from https:/unctad.org/system/files/officialdocument/ditctab20102_en.pdf

Ohashi, H. (2018a). The Belt and Road Initiative (BRI) in the context of China's opening-up policy. Journal of Contemporary East Asia Studies, 7(2), 85-103.

Belt and Road Initiative. Retrieved September 19, 2020, from https://www.beltroadinitiative.com/belt-and-road/

Ohashi, H, (2018b). The Belt and Road Initiative (BRI) in the context of China's opening-up policy. Journal of Contemporary East Asia Studies, 7(2), 85-103.

Ruta, M. (2018). Three Opportunities and Three Risks of the Belt and Road Initiative. Retrieved September 20, 2020, from https://blogs.worldbank.org/trade/three-opportunities-and-three-risksbelt-and-road-initiative

Khurana G.S, (2019). India as a Challenge to China's BRI. Retrieved September 20,2020, from https://maritimeindia.org/india-as-a-challenge-to-chinas-bri/

Stuart, D.T. (2016). The Pivot To Asia: Can It Serve As The Foundation For American Grand Strategy In The $21^{\text {st }}$ Century? (Monograph, US Army War College, 2016),24, Retrieved August 21, 2020, from https://publications.armywarcollege.edu/pubs/2395.pdf

Cooper, Z, and Shearer, A. (2017). Thinking clearly about China's layered Indo-Pacific Strategy. Bulletin of the Atomic Scientists, 73(5), 305-311.

Blackwill, D.R. (2019).Trump's Foreign Policies Are Better than They Seem. Retrieved July 22, 2020 from https://www.cfr.org/sites/default/files/report_pdf/CSR\%2084_Blackwill_Trump.pdf

Scott, D. (2018). The Indo-Pacific in US Strategy: Responding to Power Shifts. Rising Powers Quaterly, 3(2), 19-43.

Department of State, USA. (2019a). Department of State, United States of America. Retrieved July 28, 2020, from https://www.state.gov/wp-content/uploads/2019/11/Free-and-Open-Indo-Pacific4Nov2019.pdf

Vorndick, W. (2018). China's Reach Has Grown; So Should The Island Chains. Retrieved September 23, 2020, from https://amti.csis.org/chinas-reach-grown-island-chains/ 
Davidson, P (2020). U.S. Indo-Pacific Command. Retrieved September 22, 2020, from https://www.pacom.mil/Media/Speeches-Testimony/Article/2085461/the-united-states-interestsin-the-indo-pacific/

Mehta, A. (2020). Inside US Indo-Pacific Commands'\$20 billion wish list to deter China-and why Congress may approve it. Retrieved September 29, 2020, from https://www.defensenews.com/global/asia-pacific/2020/04/02/inside-us-indo-pacific-commands20-billion-wish-list-to-deter-china-and-why-congress-may-approve-it/

Department of State, USA (2019b). Department of State, United States of America. Retrieved July 28, 2020, from https://www.state.gov/wp-content/uploads/2019/11/Free-and-Open-Indo-Pacific4Nov2019.pdf

Agence France-Presse (2018). Apec summit fails to agree on statement amid US-China spat. Retrieved September 23, 2020, from https:/www.theguardian.com/world/2018/nov/18/apecsummit-mike-pence-warns-of-chinas-constricting-belt-and-one-way-road

Pitakdumrongit, K.K. (2019). The Impact of the Trump Administration's Indo-Pacific Strategy on Regional Economic Governance (Policy Studies 79, East-West Center), 15, Retrieved September 24 , 2020 , from https://www.eastwestcenter.org/system/tdf/private/ewc_policy_studies_79_web.pdf?file=1\&type $=$ node $\&$ id $=37123$

Mahbubani K.\&Sng J. (2017). The ASEAN Miracle: A Catalyst for Peace. New Delhi, India: Oxford University Press. Pp.82

Ibid. Pp.99-100.

Keithley, S. (2014). China's New Global Institutions. Retrieved October 07, 2020, from https://thediplomat.com/2014/07/chinas-new-global-institutions/

Gujral, I.K. (1996), 'Statement by His Excellency Mr. I.K. Gujral: Minister of External Affairs and Water Resources of India', Singapore, Retrieved September 04, 2020, from http://www.aseansec.org/4756.

Ministry of External Affairs, Government of India. (2018). Retrieved October 07, 2020, from https://www.mea.gov.in/Speeches-

Statements.htm?dt1/29943/Prime+Ministers+Keynote+Address+at+Shangri+La+Dialogue+June $+01+2018$

Indo-Pacific Division Briefs, Ministry of External Affairs, (2020). Retrieved September 06, 2020, from https://mea.gov.in/Portal/ForeignRelation/Indo_Feb_07_2020.pdf

Ibid.

Dixit, R. (2019). Modi's 2.0 foreign policy to lay stress on 'SAGAR Doctrine' and 'Act East', Retrieved September 08, 2020, from https://www.theweek.in/news/india/2019/06/06/modiforeign-policy-lay-stress-sagar-doctrine-and-act-east.html 
Western Indian Ocean Marine Science Association, Retrieved September 09, 2020, from https://www.wiomsa.org/about-wiomsa/

Indian Navy, Ministry of Defence (2015). Ensuring Secure Seas: Indian Maritime Security

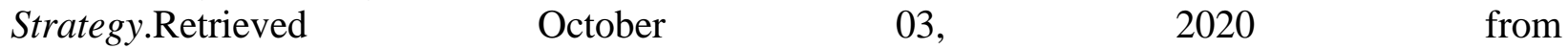
https://www.indiannavy.nic.in/sites/default/files/Indian_Maritime_Security_Strategy_Document _25Jan16.pdf

Singh, A. (2015). Evaluating India-Africa Maritime Relations. Retrieved September 09, 2020, from https://thediplomat.com/2015/10/evaluating-india-africa-maritime-relations/

Todi, S. (2019). India Gets Serious About the Indo-Pacific. Retrieved September 09, 2020, from https://thediplomat.com/2019/12/india-gets-serious-about-the-indo-pacific/

Swarajya (2019). Explained: India Navy's Information Fusion Centre For Indian Ocean Region, Why It Is Critical To India's Interests. Retrieved September 11, 2020, from https://swarajyamag.com/news-brief/explained-india-navys-information-fusion-centre-forindian-ocean-region-why-it-is-critical-to-indias-interests

Wagner, C. (2019).India's Africa Policy. Retrieved October 16, 2020, from https://www.swpberlin.org/fileadmin/contents/products/research_papers/2019RP09_wgn_Web.pdf Ibid.

Mishra A. (2019). India-Africa Maritime Cooperation: The case of Western Indian Ocean. Retrieved September 26, 2020, from https://www.orfonline.org/research/india-africa-maritimecooperation-the-case-of-western-indian-ocean-57250/

Levesques, A. \& Solanki, V. (2020a). India-US relations in the age of Modi and Trump. Retrieved September 15, 2020, from https://www.iiss.org/blogs/analysis/2020/03/sasia---us-india-relationstrump-and-modi

Scott, D. (2013). India's Aspirations and Strategy for the Indian Ocean- Securing the Waves?, Journal of Strategic Studies, 36(4), 484-511.

Ayres, A. (2020a). A Field Guide to US-India Trade Tensions. Retrieved September 14, 2020, from https://www.cfr.org/article/field-guide-us-india-trade-tensions

Levesques, A. \& Solanki, V. (2020b). India-US relations in the age of Modi and Trump. Retrieved September 15, 2020, from https://www.iiss.org/blogs/analysis/2020/03/sasia---us-india-relationstrump-and-modi

The Economic Times (2018). Seven reasons why COMCASA is so important for India. Retrieved September 16, 2020, from https://economictimes.indiatimes.com/news/defence/seven-reasonswhy-comcasa-is-so-important-for-india/articleshow/65707682.cms 
Department of Defense (2019). The Department of Defense. Indo-Pacific Strategy Report. Retrieved September 28, 2020, from https://media.defense.gov/2019/Jul/01/2002152311/-1/1/1/DEPARTMENT-OF-DEFENSE-INDO-PACIFIC-STRATEGY-REPORT-2019.PDF

Ayres, A. (2020b). A Field Guide to US-India Trade Tensions. Retrieved September 14, 2020, from https://www.cfr.org/article/field-guide-us-india-trade-tensions

Campbell K \& Doshi R (2020). The Coronavirus Could Reshape Global Order. Retrieved September 27, 2020, from https://www.foreignaffairs.com/articles/china/2020-03-18/coronaviruscould-reshape-global-order

Haider, S (2020). India-U.S to collaborate on COVID-19 vaccine trials, says U.S health officials. Retrieved September 28, 2020, from https://www.thehindu.com/news/national/coronavirus-indiaus-to-collaborate-on-covid-19-vaccine-trials-say-us-health-officials/article31626539.ece 